\title{
分子印迹型CNT/ZnO的制备及其光催化降解双酚 $\mathrm{A}$
}

\author{
苏立强，李国武, 兰志满, 于亭亭, 初红涛, 韩爽, 秦世丽 \\ 齐齐哈尔大学化学与化学工程学院, 齐齐哈尔 161006 \\ *联系人, E-mail: slq202@163.com
}

2019-10-11 收稿, 2019-12-18 修回, 2020-01-20 接受, 2020-02-09 网络版发表

黑龙江省自然科学基金(QC2018073)、黑龙江省教育厅科研项目(135109201)和齐齐哈尔大学研究生创新项目(YJSCX2018-016X)资助

\begin{abstract}
摘要 利用光催化技术解决水污染问题一直是环境领域的研究热点. 实际应用中, 高浓度低毒性的共存物对低浓 度高毒性的目标物的降解产生很大的影响。如何有效地避免此类物质的千扰，达到对目标物的最大化降解效果是 目前亟须解决的问题. 本研究通过利用分子印迹技术对 CNT/ZnO进行改性, 得到分子印迹型光催化材料(MIP$\mathrm{CNT} / \mathrm{ZnO})$ ，研究了其在不同环境体系中对双酚 $\mathrm{A}$ 的降解能力。结果表明，印迹聚合物成功包覆在 $\mathrm{CNT} / \mathrm{ZnO}$ 表面， MIP-CNT/ZnO仍保持和 $\mathrm{ZnO}$ 一样的纤锌矿结构, 对双酚 $\mathrm{A}$ 的吸附量能够达到 $7.23 \mathrm{mg} / \mathrm{g}$, 是其结构类似物已烯雌酚 和苯酚的 1.69 和 1.65 倍. 经紫外光照射 $210 \mathrm{~min}$ 后, 对单一体系中双酚 $\mathrm{A}$ 的降解率为 $83.44 \%$, 对混合体系中双酚 $\mathrm{A}$ 的 降解率可达 $76.43 \%$, 能够有效避免高浓度共存物质的千扰而选择性地降解双酚 $\mathrm{A}$, 为去除水中低浓度高毒性的有 机污染物提供了一种可能的途径.
\end{abstract}

关键词 $\mathrm{ZnO}$, 双酚 $\mathrm{A}$, 分子印迹, 光催化, 催化剂

双酚 $\mathrm{A}(\mathrm{BPA})$ 是一种重要的有机化工原料，同时也 是一种典型的内分泌干扰素，随着塑料制品的大量使 用, 每年有超过 100 t的BPA转移至环境中, 已经被列为 继臭氧空洞和温室效应之后迫切需要治理的“第三代 环境污染物”. BPA经环境进人人体后会逐渐在体内蓄 积, 干扰正常的激素分泌, 严重威胁着人体健康. 因此, 寻求一种能有效降低环境中BPA浓度的方法越来越重 要. 目前, 处理BPA的主要方法有生物法、吸附法、电 化学法、臭氧氧化法和光催化氧化技术等 ${ }^{[1>8]}$.

光催化氧化技术是一种环境友好型净化技术，具 有反应条件温和、操作简单且不产生二次污染等优点, 被认为是改善环境污染问题的有效方法之一. 然而, 该 技术因缺乏选择性而使得降解效果不够理想 ${ }^{[9,10]}$, 在催 化过程中, 催化材料会优先降解高浓度低毒性的物质, 低浓度高毒性的物质因得不到有效降解继续存在于环
境中, 随着生物链最终转移至人体, 给人体健康带来危 害, 因此亟须开发一种能够在复杂环境中选择性降解 污染物的技术. 分子印迹技术最突出的特点就是特异 识别性，印迹聚合物因含有与模板分子相匹配的印迹 孔穴，能够选择性地在复杂基质中识别并富集目标分 子. 将光催化氧化技术和分子印迹技术相结合, 可以弥 补其缺乏选择性的不足.

2007年, Shen课题组 ${ }^{[11,12]}$ 将分子印迹聚合物包覆 在 $\mathrm{TiO}_{2}$ 表面, 提升其选择性, 该方法的研究引起人们的 关注. Chai等人 ${ }^{[13]}$ 利用低温液相沉积和原位聚合技术, 以双酚 $\mathrm{A}$ 为模板分子制备了分子印迹型纳米电极, 该电 极经 $2 \mathrm{~h}$ 反应后对BPA的降解率能够达到 $97 \%$, 降解动 力学常数可达 $1.76 \mathrm{~h}^{-1}$, 并表现出优异的选择性. Feng 等人 ${ }^{[14]}$ 利用原子转移自由基聚合技术在 $\mathrm{ZnO}$ 表面接枝 了一层温敏型的聚合物，该材料能够通过控制温度来

引用格式: 苏立强, 李国武, 兰志满, 等. 分子印迹型CNT/ZnO的制备及其光催化降解双酚A. 科学通报, 2020, 65: 1368-1375 Su L Q, Li G W, Lan Z M, et al. Preparation of molecularly imprinted CNT/ZnO and photocatalytic degradation of bisphenol A (in Chinese). Chin Sci Bull, 2020, 65: 1368-1375, doi: 10.1360/TB-2019-0617 
实现可控的选择性光催化. Cantarella等人 ${ }^{[15]}$ 将扑热息 痛印迹在氧化锌纳米管表面，得到分子印迹氧化锌纳 米管光催化材料, 用于选择性催化降解扑热息痛. 该材 料在紫外光照射 $3 \mathrm{~h}$ 后对扑热息痛的去除率可达 $100 \%$. Atarodi等人 ${ }^{[16]}$ 以壳聚糖为原料, 环氧氯丙烷为交联剂, 阿特拉津为模板分子，合成了一种分子印迹纳米光催 化剂. 在紫外光照射 $10 \mathrm{~h}$ 后，对浓度为 $90 \mathrm{mg} / \mathrm{L}$ 的阿特 拉津的去除率为 $80.29 \%$, 并表现出良好的选择性.

目前用于改善光催化材料选择性的研究大都以 $\mathrm{TiO}_{2}$ 为基质, 而 $\mathrm{ZnO}$ 作为光催化材料的研究热点之一, 具有廉价易得、无毒等特点, 尚未见关于在碳纳米管 (CNT)/ZnO基质上进行分子印迹改性的相关研究. 本 研究以双酚 $\mathrm{A}$ 为模板分子, 以 $\mathrm{CNT} / \mathrm{ZnO}$ 为基质制备分 子印迹型光催化材料(MIP-CNT/ZnO), 考察其对双酚A 的吸附能力、降解能力以及选择性. 结果表明, 该分子 印迹型光催化材料不仅对双酚 $\mathrm{A}$ 有着良好的吸附能力 和选择性，而且能够在有高浓度物质共存的体系中选 择性地降解双酚 $\mathrm{A}$, 降解效果令人满意, 为除去水中低 浓度高毒性污染物提供了一种可能的途径.

\section{1 实验}

( i ) 主要原料及试剂. 乙酸锌、十二烷基硫酸钠 $(\mathrm{SDS})$ 、双酚 $\mathrm{A}(\mathrm{BPA}) 、 2$-乙烯基吡啶(2-VP)、乙二醇 二甲基丙烯酸酯(EGDMA)、偶氮二异丁腈(AIBN)和 无水乙醇均为分析纯，以上试剂均购于天津市科密欧 化学试剂有限公司; 多壁碳纳米管购于北京百灵威科 技有限公司。

(ii) $\mathrm{CNT} / \mathrm{ZnO}$ 的制备. 参照文献[17], 取适量多壁 碳纳米管(MWCNT) 经马弗炉 $400^{\circ} \mathrm{C}$ 纯化处理，除去杂 质和不定型碳. 然后, 取一定量纯化后的多壁碳纳米管 于质量分数为 $2 \%$ 的十二烷基硫酸钠(SDS)溶液中, 超声 处理. 取 $0.5 \mathrm{~g}$ SDS处理过的MWCNT于 $50 \mathrm{~mL}$ 水和乙醇 的混合液中(体积比 $=1: 1$ ), 超声 $15 \mathrm{~min}$. 将 $2.45 \mathrm{~g}$ 二水乙 酸锌溶于 $50 \mathrm{~mL}$ 水和乙醇的混合液中 (体积比 $=1: 1)$, 在 持续搅拌下将乙酸锌溶液滴人上述MWCNT悬浮液中. 将盛有混合液的烧杯置于加热板上加热以除去溶液中 的乙醇和水，最后将得到的粉末于马弗炉中 $300^{\circ} \mathrm{C}$ 加热 $3 \mathrm{~h}$, 随炉冷却得到 $\mathrm{CNT} / \mathrm{ZnO}$ 粉体.

(iii) MIP-CNT/ZnO的制备. 将 $0.283 \mathrm{~g}(1 \mathrm{mmol})$ 模 板分子BPA溶于无水乙醇中，加人 $0.6308 \mathrm{~g}(6 \mathrm{mmol})$ 功 能单体 2 -乙烯基吡啶，室温下预聚合 $4 \mathrm{~h}$. 加人 CNT/ $\mathrm{ZnO}$ 粉体并超声处理，再加人 $3.9640 \mathrm{~g}(20 \mathrm{mmol})$ 交联剂
EGDMA和 $40 \mathrm{mg}$ 引发剂AIBN, 将混合液通 $\mathrm{N}_{2} 20 \mathrm{~min}$ 除 氧密封，于 $60^{\circ} \mathrm{C}$ 下聚合反应 $24 \mathrm{~h}$. 反应结束后用无水乙 醇和去离子水冲洗数次，再经甲醇/乙酸混合液索氏提 取, 直至完全除去模板分子, 将得到的样品用去离子水 洗至中性, 于真空干燥箱中 $60^{\circ} \mathrm{C}$ 干燥 $6 \mathrm{~h}$, 得到分子印迹 型光催化材料(MIP-CNT/ZnO). 在不加模板分子的情 况下制备非分子印迹型光催化材料(NIP-CNT/ZnO), 操 作步骤同上.

(iv) 催化剂的表征. 采用傅立叶变换红外光谱仪 AS380(美国尼高力公司)对样品的官能团进行分析，扫 描波长范围为 $4000 \sim 400 \mathrm{~cm}^{-1}$, 分辨率为 $\pm 2 \mathrm{~cm}^{-1}$; D/ Max-III C型X射线衍射仪(XRD，日本理学公司)对样品 的晶相结构进行分析，扫描范围为 $5^{\circ} \sim 80^{\circ}$, 扫描速度 10\% min; H-7650型透射电子显微镜(TEM, Hitachi公司) 对样品的微观结构进行分析.

（v）吸附性能的考察．取 $10 \mathrm{mg} / \mathrm{L}$ 的双酚 $\mathrm{A}$ 、已烯 雌酚和苯酚溶液于吸附瓶中, 加人 $0.02 \mathrm{~g}$ 印迹材料, 使 其充分摇匀，于避光条件下静置 $24 \mathrm{~h}$, 取上清液过 $0.45 \mu \mathrm{m}$ 滤膜后，利用紫外分光光度法测量吸光度，并 按式(1)计算吸附量:

$Q=\left(C_{0}-C_{\mathrm{e}}\right) V / m$,

式中, $C_{0}$ 为目标物初始浓度, $C_{\mathrm{e}}$ 为平衡浓度, $V$ 为溶液体 积, $m$ 为材料质量.

(vi) 光催化活性评价. 取 $100 \mathrm{~mL}$ 浓度为 $10 \mathrm{mg} / \mathrm{L}$ 的 BPA溶液置于反应管中，加人一定量的印迹光催化材 料于自制光催化反应仪中. 开启磁力搅拌器使催化剂 颗粒处于悬浮状态，避光搅拌30 min至吸附平衡后(预 备实验证明 $30 \mathrm{~min}$ 基本处于吸附平衡)，用紫外灯 $(20 \mathrm{~W}, 365 \mathrm{~nm})$ 照射反应液进行降解反应，每隔30 min 取样，离心分离后取上清液. 利用TU-1901型紫外/可见 分光光度计检测其吸光度，然后根据朗伯-比尔定律计 算浓度, 并按式(2)计算降解率:

$\eta=\left[\left(C_{0}-C_{\mathrm{t}}\right) / C_{0}\right] \times 100 \%$,

式中, $C_{0}$ 和 $C_{\mathrm{t}}$ 分别为 $\mathrm{BPA}$ 初始浓度和降解 $t$ 时间后的 浓度.

\section{2 结果与讨论}

\subsection{FTIR分析}

对CNT, CNT/ZnO, MIP-CNT/ZnO(含模板)和MIP$\mathrm{CNT} / \mathrm{ZnO}$ 进行了红外分析(图1). 由图1可知, $3421 \mathrm{~cm}^{-1}$ 


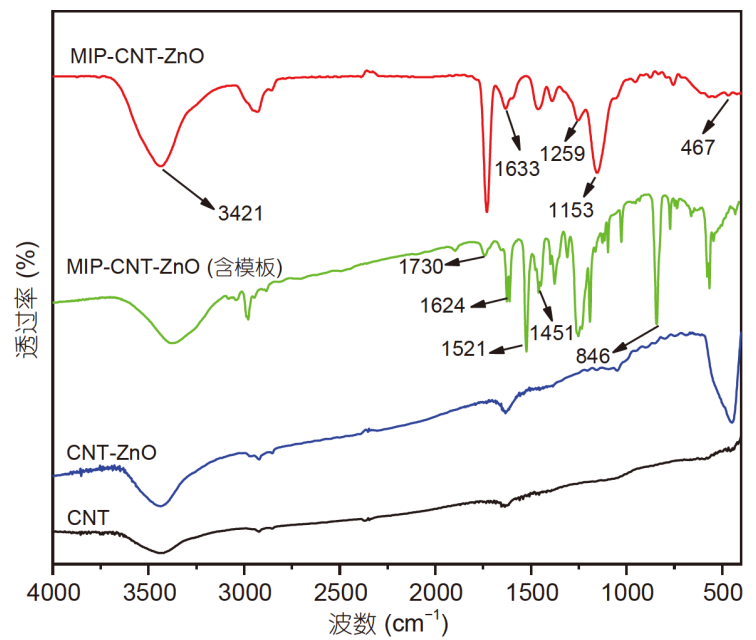

图 1 (网络版彩色)MIP-CNT/ZnO, MIP-CNT/ZnO(含模板), CNT/ $\mathrm{ZnO}$ 和CNT的红外光谱

Figure 1 (Color online) FTIR spectra of MIP-CNT/ZnO, MIP-CNT/ $\mathrm{ZnO}$ (with template), $\mathrm{CNT} / \mathrm{ZnO}$ and $\mathrm{CNT}$

处为 $-\mathrm{OH}$ 的伸缩振动吸收峰, 与 CNT相比, CNT/ZnO的 红外光谱中新增了 $467 \mathrm{~cm}^{-1}$ 左右的吸收峰, 此吸收峰为 $\mathrm{Zn}-\mathrm{O}$ 的特征伸缩振动峰, 说明 $\mathrm{CNT} / \mathrm{ZnO}$ 合成成功. 相 比于 $\mathrm{CNT} / \mathrm{ZnO}$ 的红外光谱, MIP-CNT/ZnO(含模板)的 红外光谱中, 新增的吸收峰分别为 $1730 \mathrm{~cm}^{-1}$ 处 $\mathrm{C}=\mathrm{O}$ 的 伸缩振动吸收峰和 $1624,1521,1451$ 和 $846 \mathrm{~cm}^{-1}$ 处苯环 结构的特征吸收峰. 其中, $\mathrm{C}=\mathrm{O}$ 是来源于EDGMA和2$\mathrm{VP}$ 的聚合物, 苯环结构的吸收峰来源于模板分子 BPA, 这些特征峰的出现说明在 $\mathrm{CNT} / \mathrm{ZnO}$ 表面包覆了含模板 双酚A的聚合物. 和MIP-CNT/ZnO(含模板)相比, MIP$\mathrm{CNT} / \mathrm{ZnO}$ 的红外光谱中苯环结构的特征峰消失, 说明 模板分子双酚A已洗脱, 印迹聚合物制备成功.

\subsection{XRD分析}

对MIP-CNT/ZnO, CNT/ZnO和CNT进行了 XRD分 析, 结果如图2所示. CNT图(图2(c))中26.54为碳纳米 管的衍射峰，对应JCPDS卡片库碳纳米管(41-1487)的 (002)晶面. $\mathrm{CNT} / \mathrm{ZnO}$ 图(图2(b))中31.94 $4^{\circ}, 34.48^{\circ}, 36.3^{\circ}$, $47.58^{\circ}, 56.7^{\circ}, 62.94^{\circ}, 66.48^{\circ}, 68.12^{\circ}, 69.2^{\circ}$ 处的衍射峰 与六方晶系纤锌矿 $\mathrm{ZnO}(\mathrm{JCPDS}$ No. 36-1451)一致, 对应 晶面为(100), (002), (101), (102), (110), (103), (200), (112), (201)面, 说明所制备的 $\mathrm{CNT} / \mathrm{ZnO}$ 为六方晶系纤 锌矿结构. MIP-CNT/ZnO图(图2(a))的衍射峰峰型尖 锐, 半峰宽较窄, 说明结晶度较好, 且未出现其他杂峰, 说明制得的样品纯度较高. 根据Scherrer公式, 通过 (101)晶面对应的半高宽计算得样品中 $\mathrm{ZnO}$ 的平均粒径

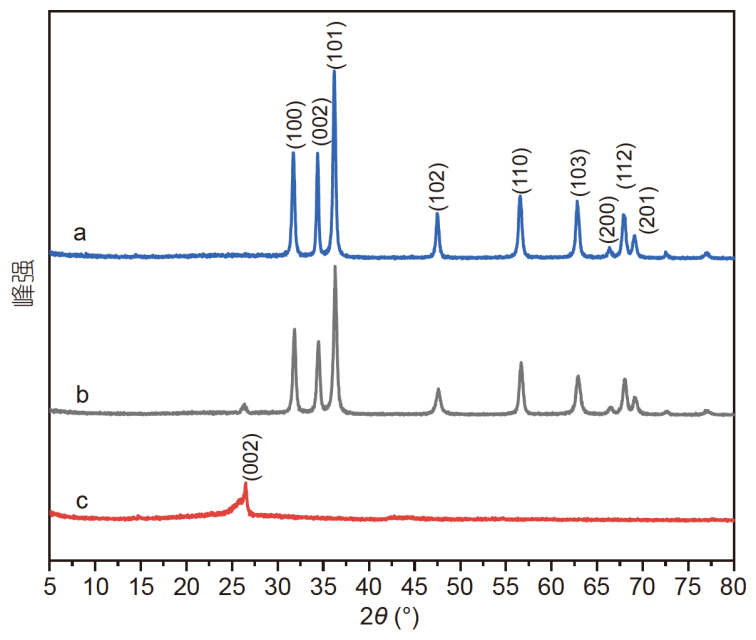

图 2 (网络版彩色) MIP-CNT/ZnO(a)、CNT/ZnO(b)和CNT(c)的 XRD谱

Figure 2 (Color online) XRD spectra of MIP-CNT/ZnO (a), CNT/ $\mathrm{ZnO}$ (b) and $\mathrm{CNT}(\mathrm{c})$

为 $80 \mathrm{~nm}$.

\subsection{TEM分析}

从图3(a)可以看出, CNT为管状结构, 表面较为光 滑, 呈卷曲状态. $\mathrm{ZnO}$ 成功附着在 $\mathrm{CNT}$ 上, 但是出现部分 团聚现象图3(b), 这可能是因为纳米氧化锌本身具有的 较高的比表面能所致. 从图3(c) 可看出聚合物包覆在 $\mathrm{CNT} / \mathrm{ZnO}$ 表面, 同时在MIP-CNT/ZnO的HRTEM图(图3 (d))中可以清晰地看到 $\mathrm{ZnO}$ 的晶格条纹，其晶面间距约 为 $0.25 \mathrm{~nm}$, 对应(002)面间距; 并可以看到 CNT的晶格

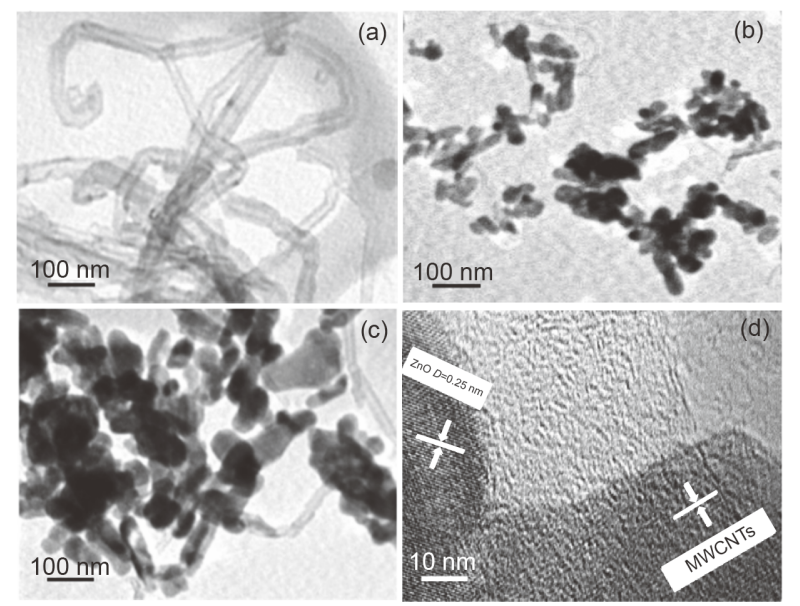

图 $3 \mathrm{CNT}(\mathrm{a}), \mathrm{CNT} / \mathrm{ZnO}(\mathrm{b})$ 和MIP-CNT/ZnO(c)的TEM图以及MIP$\mathrm{CNT} / \mathrm{ZnO}(\mathrm{d})$ 的HRTEM图

Figure 3 TEM images of CNT (a), CNT/ZnO (b), MIP-CNT/ZnO (c) and HRTEM images of MIP-CNT/ZnO (d) 
条纹, 其相邻壁的点阵间距约为 $0.34 \mathrm{~nm}$, 符合石墨的层 间距. 包覆在表面的印迹层为非晶结构, 因此没有晶格 条纹.

\subsection{TG分析}

对MIP-CNT/ZnO进行热重分析，结果如图4所示. 随着温度的升高, MIP-CNT/ZnO出现两处失重过程, 其中 $100 \sim 200^{\circ} \mathrm{C}$ 的失重是因为材料表面溶剂和水的挥 发, 失重率为 $1.54 \% ; 250 \sim 550^{\circ} \mathrm{C}$ 的失重是因为印迹层的 逐步分解, 总失重率为 $17.71 \%$, 由此可知 $\mathrm{CNT} / \mathrm{ZnO}$ 表面 印迹层的包覆量约为 $223.36 \mathrm{mg} / \mathrm{g}$.

\section{5 光催化效率的考察}

采用4种材料 $\mathrm{ZnO}, \mathrm{CNT} / \mathrm{ZnO}, \mathrm{MIP}-\mathrm{CNT} / \mathrm{ZnO}$ 和NIP$\mathrm{CNT} / \mathrm{ZnO}$ 降解BPA, 考察降解时间对降解率的影响, 并 通过准一级动力学方程拟合研究降解过程动力学, 结果 见图5. 由图 5(a)可知, 4种材料均具有一定的降解作用, 降解率随时间而增加，反应速率呈先增大后变缓的趋 势. 在 $210 \mathrm{~min}$ 时对 BPA的降解率分别为 $47.34 \%$, $59.31 \%, 83.44 \%$ 和 $36.57 \%$. 对降解过程进行准一级动力 学拟合(图 5(b)), 其中MIP-CNT/ZnO的降解速率常数为 $0.00824 \mathrm{~min}^{-1}$, 明显高于 $\mathrm{CNT} / \mathrm{ZnO}\left(0.00415 \mathrm{~min}^{-1}\right), \mathrm{ZnO}$ $\left(0.00302 \mathrm{~min}^{-1}\right)$ 和NIP-CNT/ZnO $\left(0.00212 \mathrm{~min}^{-1}\right)$, 分别 是其1.98，2.72和3.88倍, 说明MIP-CNT/ZnO对BPA的 光催化降解活性最好. $\mathrm{ZnO}$ 作为一种常用的光催化材 料, 具有能带宽、成本低等优点 ${ }^{[18]}$, 在本研究中对BPA 表现出良好的催化降解效果，降解率达 $47.34 \% . \mathrm{CNT} /$ $\mathrm{ZnO}$ 的降解率较 $\mathrm{ZnO}$ 有所提高, 达到 $59.31 \%$, 这是因为

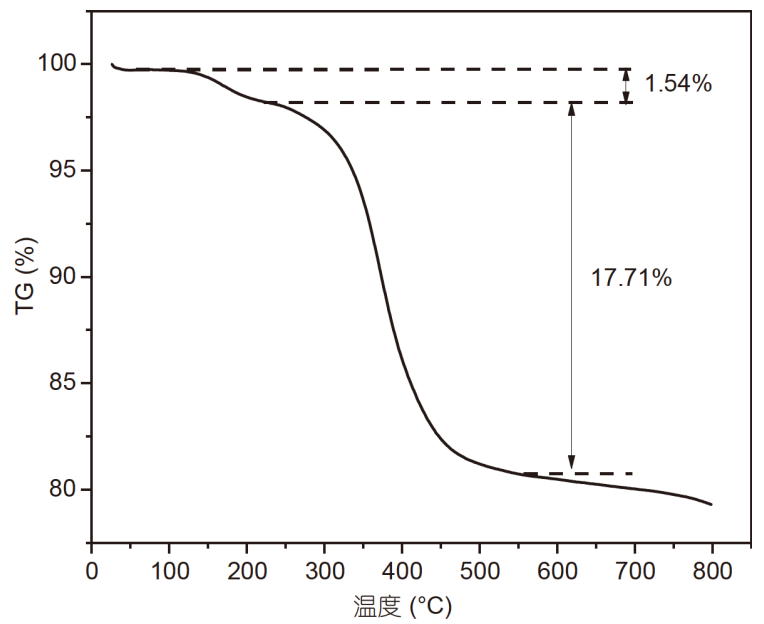

图 4 MIP-CNT/ZnO的热重分析曲线

Figure 4 TGA curve of MIP-CNT/ZnO

CNT作为光生电子受体, 能够快速转移电子, 降低光生 电子-空穴对的复合, 提高了催化活性, 所以其降解率有 所提高. 相比于 $\mathrm{CNT} / \mathrm{ZnO}, \mathrm{MIP}-\mathrm{CNT} / \mathrm{ZnO}$ 的降解率又有 所提高, 达到 $83.44 \%$, 这是由于表面包覆的印迹聚合物 含有与BPA相匹配的“记忆孔穴”, 能够特异性地识别并 吸附该分子，对BPA起到富集的作用，因此降解得更加 完全. 而NIP-CNT/ZnO的降解率最低(仅有36.57\%), 这 是因为非印迹聚合物的包覆阻碍了BPA分子与催化材 料的接触, 所以其降解率低于 $\mathrm{ZnO}$ 和 $\mathrm{CNT} / \mathrm{ZnO}$.

\section{6 吸附实验}

为了考察聚合物的吸附能力，选用与双酚 $\mathrm{A}$ 结构相 近的已烯雌酚和苯酚作为竞争底物，进行吸附实验，通
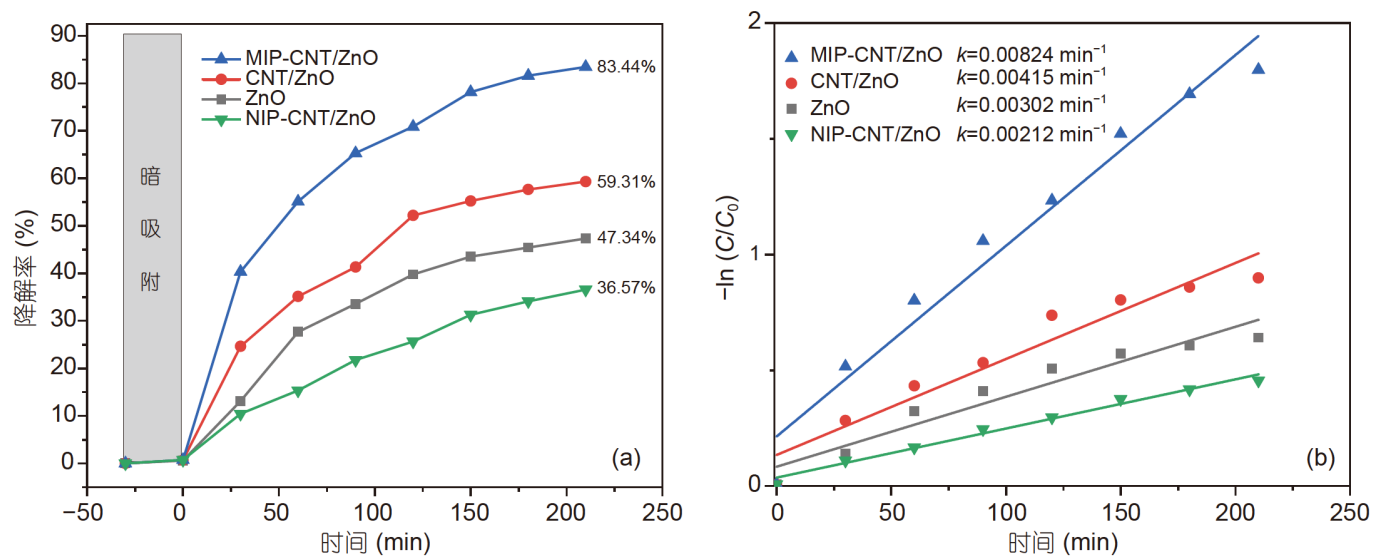

图 5 (网络版彩色)MIP-CNT/ZnO, CNT/ZnO和 ZnO的光催化降解曲线(a)和降解过程准一级动力学拟合曲线 (b)

Figure 5 (网络版彩色) Photocatalytic degradation curves (a) and pseudo-first-order reaction kinetics of BPA over MIP-CNT/ZnO, CNT/ZnO, ZnO and NIP-CNT/ZnO (b) 

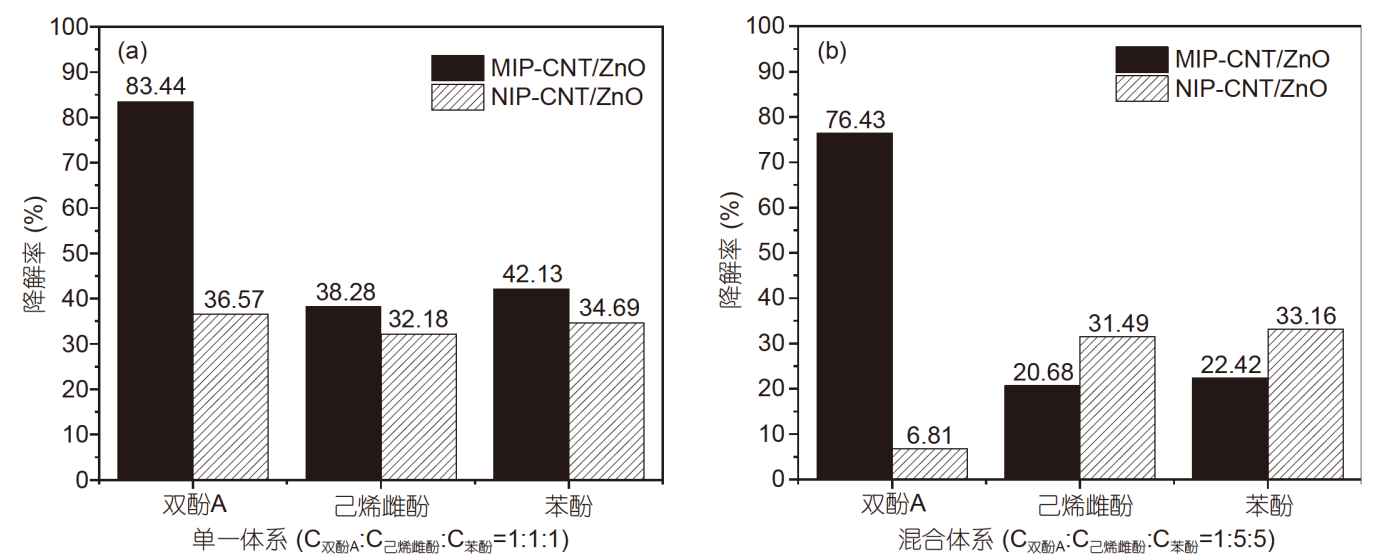

图 6 MIP-CNT/ZnO和NIP-CNT/ZnO对不同底物的催化降解图. (a) 单一体系; (b) 混合体系

Figure 6 Catalytic degradation of MIP-CNT/ZnO and NIP-CNT/ZnO for different targets. (a) Single component; (b) mixed components

过吸附量 $Q$ 来表征MIP和NIP吸附能力. MIP对双酚A的 吸附量为 $7.23 \mathrm{mg} / \mathrm{g}$ ，明显大于己烯此酚 $(4.28 \mathrm{mg} / \mathrm{g}$ )和苯 酚 $(4.36 \mathrm{mg} / \mathrm{g})$, 吸附量分别是后两者的 1.69 和 1.65 倍, 差 别明显. 这是因为MIP表面具有和双酚A相匹配的印迹 孔穴, 因此对双酚 $\mathrm{A}$ 的吸附效果好, 吸附量最大; 对于己 烯雌酚和苯酚，由于印迹孔穴和二者匹配程度低，所以 吸附效果差, 吸附量低. NIP因为没有印迹孔穴, 对3种底 物的吸附量均较小且无明显差别(双酚 $\mathrm{A}(4.54 \mathrm{mg} / \mathrm{g})$ 、 己烯雌酚 $(3.93 \mathrm{mg} / \mathrm{g})$ 和苯酚 $(4.21 \mathrm{mg} / \mathrm{g}))$.

\section{7 选择性实验}

为考察印迹光催化材料的选择性，分别选择己烯 雌酚和苯酚作为模板双酚 $\mathrm{A}$ 的竞争底物, 进行单一体系 和混合体系的光催化实验. 在单一体系中, 双酚A:己烯 雌酚: 苯酚的浓度比为 $1: 1: 1$, 由图6(a)可知, MIP-CNT/ $\mathrm{ZnO}$ 对双酚 $\mathrm{A}$ 的降解率分别是已烯䧳酚和苯酚的 2.18 和 1.98 倍, 这是由于MIP-CNT/ZnO 表面具有和BPA分子 相匹配的印迹孔穴和识别位点，能够专一性地吸附 BPA，对BPA起到富集作用，所以对其有高的降解率. 己烯雌酚和苯酚的结构与MIP-CNT/ZnO表面的印迹孔 穴不匹配，只能通过简单的物理吸附作用存在于MIP$\mathrm{CNT} / \mathrm{ZnO}$ 表面, 降解率远不如双酚A. 而NIP-CNT/ZnO 对双酚 $\mathrm{A}$ 的降解率仅是后两者的 1.13 和 1.05 倍, 三者的 降解率相差不大, 是因为NIP-CNT/ZnO没有印迹孔穴 和结合位点, 对 3 种底物的吸附均为物理吸附及非特异 性催化降解, 因此降解率均不高且无明显差异. 在混合 体系中, 双酚 $\mathrm{A}$ :已烯雌酚:苯酚的浓度比为 $1: 5: 5$, 由 图6(b)可知, MIP-CNT/ZnO对双酚A的降解率能够达到
后两者的3.82和3.52倍, 说明在混合体系中, MIP-CNT/ $\mathrm{ZnO}$ 能够有效避免高浓度共存物质的干扰而选择性地 降解双酚A. NIP-CNT/ZnO对双酚A的降解率远不如后 两者, 这是因为NIP-CNT/ZnO的非特异性吸附降解行 为会优先降解浓度高的已烯雌酚和苯酚, 使得浓度低 的双酚 $\mathrm{A}$ 得不到有效降解.

\section{8 重复性实验}

为考察MIP-CNT/ZnO的稳定性, 降解实验后对 MIP-CNT/ZnO回收、洗脱、干燥, 进行了5次重复性实 验, 结果见图7. 由图7可知, 随着实验次数的增加, 降解 率和吸附量均有所降低, 但降低幅度不大，经5次实验 后，降解率仍在 $75 \%$ 以上，吸附量为 $6.55 \mathrm{mg} / \mathrm{g}$, 说明制 备的印迹光催化材料有着良好的稳定性. 同时, MIP-

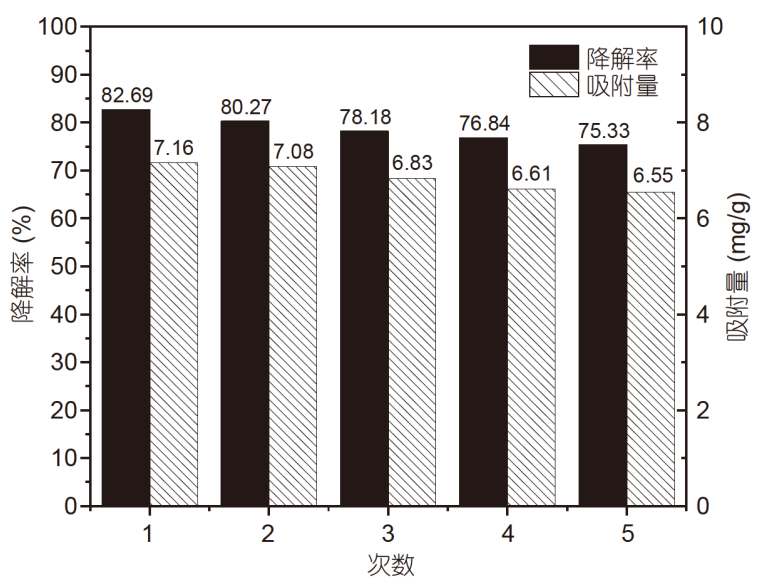

图 $7 \mathrm{MIP}-\mathrm{CNT} / \mathrm{ZnO}$ 对双酚A的重复性实验

Figure 7 Cycling experiments for the photocatalytic degradation of BPA by MIP-CNT/ZnO 

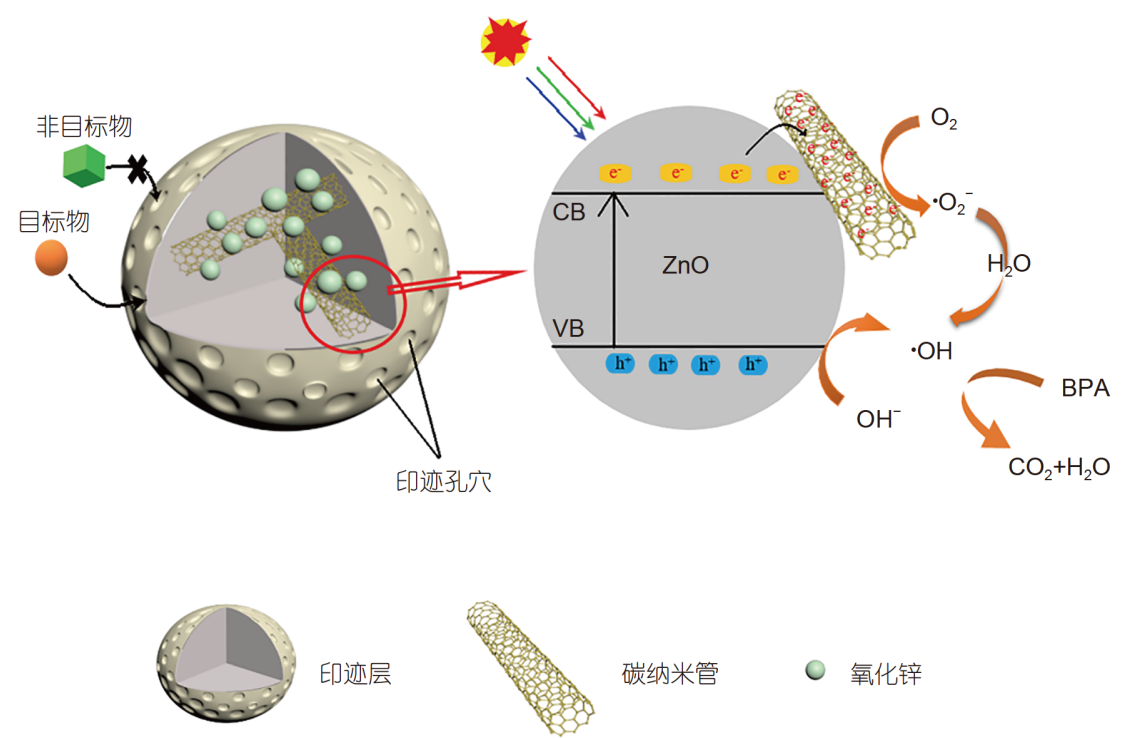

图 8 (网络版彩色)MIP-CNT/ZnO的光催化降解机理图

Figure 8 (Color online) Illustration of photo-degradation mechanism of MIP-CNT/ZnO

$\mathrm{CNT} / \mathrm{ZnO}$ 作为有机-无机复合材料, 当其重复使用一定 次数后降解效果不能令人满意时，可将其回收高温灼 烧处理, 产物为 $\mathrm{ZnO}$ 、水和 $\mathrm{CO}_{2}$, 不会对环境造成污染.

\section{9 降解机理分析}

图8为MIP-CNT/ZnO降解过程的示意图. $\mathrm{ZnO}$ 受到 等于或大于禁带能的辐射光照射时，位于价带上的电 子被激发跃迁至导带, 从而在 $\mathrm{ZnO}$ 粒子表面形成电子空穴对(式(3)). 电子经CNT转移后与空穴分离, 被环境 中的氧气捕获生成超氧自由基(式(4)), 超氧自由基和水 反应生成氢氧根离子和差基自由基(式(5)), 同时空穴和 氢氧根离子反应生成差基自由基(式(6)). 目标物因结构 和印迹孔穴相匹配所以能够通过印迹层进人内部, 进 而被具有强氧化性的羟基自由基降解为水和 $\mathrm{CO}_{2}$ (式(7)).

$\mathrm{ZnO}+h v \rightarrow \mathrm{e}^{-}+\mathrm{h}^{+}$

$\mathrm{e}^{-}+\mathrm{O}_{2} \rightarrow \cdot \mathrm{O}_{2}^{-}$

$$
\begin{aligned}
& \mathrm{O}_{2}{ }^{-}+\mathrm{H}_{2} \mathrm{O} \rightarrow \mathrm{OH}^{-}+\cdot \mathrm{OH} \\
& \mathrm{OH}^{-}+\mathrm{h}^{+} \rightarrow \cdot \mathrm{OH} \\
& \mathrm{BPA}+\cdot \mathrm{OH} \rightarrow \mathrm{H}_{2} \mathrm{O}+\mathrm{CO}_{2}
\end{aligned}
$$

\section{3 结论}

本研究通过分子印迹技术对 $\mathrm{CNT} / \mathrm{ZnO}$ 进行改性, 制备以 BPA为模板的分子印迹型光催化材料(MIP$\mathrm{CNT} / \mathrm{ZnO}$ ). 该材料表面存在与模板分子相匹配的印迹 孔穴, 模板分子被选择性地吸附和富集进而被降解. 其 对模板分子双酚 $\mathrm{A}$ 的最大吸附量为 $7.23 \mathrm{mg} / \mathrm{g}$, 降解率为 $83.44 \%$, 在单一体系和混合体系中, 从而实验均表现出 良好的选择性和降解能力. 该材料能够有效避免共存 物质的干扰达到选择性降解目标物的目的，同时保持 着良好的稳定性，经5次重复实验后，对目标物的降解 效果仍保持在 $75 \%$ 以上. 这为处理环境中低浓度高毒性 的有机污染物提供了一种可能的途径.

\section{参考文献}

1 Wang J Y, Guo Q Y, Liang J. Detection status and development trend of bisphenol A (in Chinese). Packag Eng, 2019, 40: 64-70 [王静怡, 郭启悦, 梁俊. 双酚A的检测现状及其发展趋势. 包装工程, 2019, 40: 64-70]

2 Wang S T, Cao X, Zhu H H, et al. Research progress on toxicity and detection of bisphenol A in plastic packaging materials (in Chinese). Packag Food Mach, 2019, 37: 69-72 [汪仕韬, 曹霞, 朱吴浩, 等. 塑料包装材料中双酚A毒性及检测研究进展. 包装与食品机械, 2019, 37: 69-72]

3 Zou R J, Deng X X, Wang B, et al. Effect of water and sediment adjustment of the Yellow River on bisphenol A in the Yellow River estuary (in Chinese). Acta Ecolog Sin, 2015, 35: 263-269 [邹荣婕, 邓旭修, 王斌, 等. 黄河调水调沙对黄河口海域双酚A的影响. 生态学报, 2015, 35: 263- 
269]

4 Fu M, Xing J, Ge Z. Preparation of laccase-loaded magnetic nanoflowers and their recycling for efficient degradation of bisphenol A. Sci Total Environ, 2019, 651: 2857-2865

5 Sílvia R, Cordas C M, Viveiros R, et al. Development of a ferrocenyl-based MIP in supercritical carbon dioxide: Towards an electrochemical sensor for bisphenol A. J Supercrit Fluid, 2018, 135: 98-104

6 Gao Y J. Research progress on adsorption and removal methods of BPA in water (in Chinese). Modern Chem Ind, 2019, 39: 71-75 [高艳娇. 水中 BPA的吸附去除方法研究进展. 现代化工, 2019, 39: 71-75]

7 Yan K, Yang Y H, Zhang J D. A self-powered sensor based on molecularly imprinted polymer-coupled graphitic carbon nitride photoanode for selective detection of bisphenol A. Sens Actuat B-Chem, 2018, 259: 394-401

8 Li S N, Fu D, Li F X, et al. Advanced oxidative degradation of environmental endocrine disruptors bisphenol A research progress (in Chinese). Water Treat Technol, 2018, 44: 1-6 [李胜男, 伏迪, 李凤祥, 等. 高级氧化降解环境内分泌干扰物双酚A研究进展. 水处理技术, 2018, 44: 1-6]

9 Zhou X, Lai C, Huang D, et al. Preparation of water-compatible molecularly imprinted thiol-functionalized activated titanium dioxide: Selective adsorption and efficient photodegradation of 2,4-dinitrophenol in aqueous solution. J Hazard Mater, 2018, 346: 113-123

$10 \mathrm{Wu}$ Y, Dong Y, Xia X, et al. Facile synthesis of N-F codoped and molecularly imprinted $\mathrm{TiO}_{2}$ for enhancing photocatalytic degradation of target contaminants. Appl Surf Sci, 2015, 364: 829-836

11 Shen X, Zhu L, Li J, et al. Synthesis of molecular imprinted polymer coated photocatalysts with high selectivity. Chem Commun, 2007, 11: 11631165

12 Shen X, Zhu L, Liu G, et al. Enhanced photocatalytic degradation and selective removal of nitrophenols by using surface molecular imprinted titania. Environ Sci Technol, 2008, 42: 1687-1692

13 Chai S, Zhao G, Zhang Y, et al. Selective photoelectrocatalytic degradation of recalcitrant contaminant driven by an n-P heterojunction nanoelectrode with molecular recognition ability. Environ Sci Technol, 2012, 46: 10182-10190

14 Feng Q, Tang D, Lü H, et al. Surface-initiated ATRP to modify ZnO nanoparticles with poly( $N$-isopropylacrylamide): Temperature-controlled switching of photocatalysis. J Alloys Compd, 2017, 691: 185-194

15 Cantarella M, Di Mauro A, Gulino A, et al. Selective photodegradation of paracetamol by molecularly imprinted ZnO nanonuts. Appl Catal BEnviron, 2018, 238: 509-517

16 Atarodi H, Faghihian H. Selective photodegradation of atrazine by a novel molecularly imprinted nanophotocatalyst prepared on the basis of chitosan. J Photochem Photobiol A Chem, 2019, 382: 111892

17 Bartfai E, Nemeth K, Mrabate B E, et al. Synthesis, characterization and photocatalytic efficiency of ZnO/MWCNT nanocomposites prepared under different solvent conditions. J Nanosci Nanotechnol, 2019, 19: 422-428

$18 \mathrm{Pan} \mathrm{H,} \mathrm{Hu} \mathrm{Y,} \mathrm{Wu} \mathrm{X} \mathrm{W,} \mathrm{et} \mathrm{al.} \mathrm{Preparation,} \mathrm{characterization} \mathrm{and} \mathrm{photocatalytic} \mathrm{performance} \mathrm{of} \mathrm{ZnO/CNTs} \mathrm{composites} \mathrm{(in} \mathrm{Chinese).} \mathrm{Mater} \mathrm{Rev,} \mathrm{2018,}$ 32: 4224-4229 [潘会, 胡轶, 元晓文, 等. ZnO/CNTs复合材料的制备、表征及光催化性能. 材料导报, 2018, 32: 4224-4229] 


\title{
Preparation of molecularly imprinted $\mathrm{CNT} / \mathrm{ZnO}$ and photocatalytic degradation of bisphenol A
}

\author{
Liqiang Su*, Guowu Li, Zhiman Lan, Tingting Yu, Hongtao Chu, Shuang Han \& Shili Qin \\ School of Chemistry and Chemical Engineering, Qiqihar University, Qiqihar 161006, China \\ * Corresponding author, E-mail: slq202@163.com
}

With the rapid development of industry, environmental pollution has become a focused issue in worldwide. As one of the major environment pollutants, more than 100 tons of bisphenol A (BPA) are transferred to the environment every year with the extensive use of plastic products. When BPA is ingested through the food chain, it will gradually accumulate in the body, interfere with normal hormone secretion, and pose a serious effect on human health. Therefore, it is much important to effectively eliminate the BPA in the environment. Now, the methods for treating BPA are variable. The main methods have included biological method, adsorption method, electrochemical method, ozone oxidation method and photocatalytic oxidation technology. Among them, photocatalysis has been considered as one of the effective and promising technology for the elimination of contaminants from water, owing to the advantages of high efficiency, photochemical stability and cost-efficiency. However, the main active species during photocatalysis, such as hydroxyl radicals and superoxide radicals etc., do not target at any specific compound. Thus, to the best of our knowledge, photocatalysis shows no obvious selectivity in treatment of mixed pollutants system. However, for actual wastewaters, diverse components usually coexist together, where endocrine disruptors are usually present along with other non- or low-toxic organic substances with high concentrations, such as phenolic compound. Therefore, the pollutants with high concentration would occupy the major active sites, and be degraded antecedently, which increase the difficulty and cost of wastewater treatment. The emergence of molecular imprinting technology had provided an opportunity to solve the problem of the photocatalytic activity and selectivity of photocatalyst for degradation of target contaminants, because of specific affinity and size matching between target contaminants and imprinted cavities. The combination of photocatalytic oxidation technology and molecular imprinting technology can effectively improve the selectivity of the target during photocatalysis. In order to achieve the purpose of selective degradation of BPA, a molecularly imprinted photocatalytic material (MIP-CNT/ZnO) was prepared by surface imprinting, using BPA as template molecule, 2-vinyl pyridine (2-vp) as functional monomer, ethylene glycol dimethacrylate (EGDMA) as crosslinking agent, $\mathrm{CNT} / \mathrm{ZnO}$ as supporter, respectively. The structure of MIP-CNT/ZnO was characterized by Fourier transform infrared spectroscopy (FTIR), X-ray diffraction (XRD) and transmission electron microscopy (TEM). The results showed that the imprinted polymer was successfully coated on the surface of CNT/ZnO and MIP-CNT/ZnO remained a wurtzite structure, which was the same to $\mathrm{ZnO}$. Due to the recognition site on the surface of MIP-CNT/ZnO, the degradation rate of BPA by MIP-CNT/ZnO was significantly higher than diethylstilbestrol and phenol, and the degradation rates were 2.18 and 1.98 times of the latter two, respectively. The degradation rate of BPA with initial concentration of $10 \mathrm{mg} / \mathrm{L}$ could reach $83.44 \%$ after being irradiated by ultraviolet light for $210 \mathrm{~min}$. The results demonstrated that molecularly imprinted photocatalyst exhibited excellent selectivity and catalytic ability. The present work could provide new perspectives for selective photocatalytic degradation, offer a new insight for the photocatalytic oxidation process and provide a possible way to remove low concentration and high toxicity organic pollutants in the water.

ZnO, bisphenol A, molecular imprinting, photocatalysis, catalyst

doi: 10.1360/TB-2019-0617 